\title{
Yield, biochemical properties and cooking quality traits of sweet potatoes (Ipomoea batatas) as affected by Nitrogen and Potassium Fertilizer rates
}

\author{
C. DARKO*, S. YEBOAH, A. AMOAH, A. OPOKU, E. BAAFI \& J. N. BERCHIE \\ (C.D, S.Y, E.B \& J.N.B.: CSIR-Crops Research Institute, P. O. Box 3785, Kumasi-Ghana; A.A \\ \& A.O.: Department of Crop and Soil Sciences, Kwame Nkrumah University of Science and \\ Technology, Kumasi- Ghana)
}

*Corresponding author's email: cynthiadarkob@gmail.com

\begin{abstract}
This study evaluated the effects of mineral fertilizer rates on biochemical properties, cooking quality traits and root yield of sweetpotatoes. The experimental design was $4 \times 4$ factorial in randomized complete block with three replications. The treatment factors were four varieties of sweetpotato (Ligri, Bohye, Dadanyuie and Apomuden) and four fertilizer amendments (T1: 3030-30 kg /ha NPK, T2: 30-30-60 kg NPK+50 kg Muriate of Potash, T3: 30-30-90 kg/ha NPK+ $100 \mathrm{~kg}$ Muriate of Potash and T4: Control (No fertilizer). Results showed that the fertilizer rates did not influence root yield but variety had significant difference $(\mathrm{P}<0.05)$. Apomuden recorded the highest average root yield of $14.5 \mathrm{t} /$ ha which was significantly higher than Ligri $5.1 \mathrm{t} / \mathrm{ha}$. Ligri recorded the highest dry matter and sugar contents of $34.63 \%$ and $67.98 \%$ respectively while Apomuden recorded the lowest dry matter content and starch content of $23.75 \%$ and $50.00 \%$ respectively. However, it recorded appreciable amount of beta-carotene and sugar contents of $32.38 \mathrm{mg} / 100 \mathrm{~g}$ and $28.04 \%$ respectively. There were significant variety $\times$ location interactions effect $(\mathrm{P}<0.05)$ on average root yield and biomass yield. The significant varietal response observed in this study implies that choice of variety is an important factor to consider in sweetpotato production.
\end{abstract}

Keywords: Food security; malnutrition; yield; cooking quality traits; biochemical traits; sweet potatoes

Original scientific paper. Received 20 Aug 2020; revised 28 Apr 2021

\section{Introduction}

Malnutrition caused by deficiency of vitamin $\mathrm{A}$ is a widespread phenomenon among many people in sub-Saharan Africa, including Ghana. This is because most of the cereals and the root and tuber crops consumed have low vitamin A (Obeng-Bio, 2018). A considerable proportion of the people, therefore, do not have access to nutritionally adequate food to guarantee healthy living (Waha et al., 2018). The quality of protein in food consumption in Ghana is low resulting in high mortality of children under five years due to undernutrition (FAO, 2009; GFSI, 2012). In addition, majority $(<40 \%)$ of the people cannot afford alternative protein sources such as animal products and

Ghana Jnl Agric. Sci. 56 (1), $16-25$

GJAS is an Open Access Journal and distributed under the terms of the Creative Commons (CC) License [CC BY 4.0] 
vitamin A supplementation. There is an urgent need to identify alternative food sources that can provide essential vitamins (vitamin A) to achieve better nutritional status for the population. CSIR-Crops Research Institute (CSIR-CRI) in collaboration with its partners have developed a couple of high-yielding, early maturing and vitamin-rich varieties of sweetpotato (Baafi et al., 2016). The potential exists to include high-nutrient sweetpotatoes like orange-fleshed varieties in the diet of the people as an alternative staple food source to curb malnutrition.

Sweetpotato (Ipomoea batatas) ranks fifth most important food crop in developing countries (Hoppenstedt et al., 2017). In subSaharan Africa, it is the third most important root crop after cassava and yam (Ewell \& Mutuura, 1994). It has high nutrient content which, outranked most carbohydrate foods in terms of vitamins, minerals, protein, and energy content (Onuh et al., 2005). The crop has become one of the most promising sources of beta-carotene especially the orange fleshed varieties that have high Vitamin A content (Neela \& Fanta, 2019). The crop is also used to make snacks and desserts such as pies, puddings, biscuits, cakes, crisps, mandazis and chapatis (Dumbuya et al., 2016). Despite all these benefits, root yield of sweetpotatoes remains low $(7 \mathrm{~kg} / \mathrm{ha})$ as against the potential yield of 18 to $24 \mathrm{~kg} / \mathrm{ha}$ in Ghana (CRI, 2000).

The use of soil amendments such as fertilizer to increase crop productivity is very critical. Research has shown that field experiments using soil amendments improved the yield of sweet potatoes without compromising on quality (Brobbey, 2015; Ennin et al., 2007). Nitrogen and potassium are important factors affecting yield and nutrient composition of root tubers, especially sweetpotatoes (Kareem, 2013). Nitrogen application on sweet potatoes was shown to linearly increase dry matter, carotenoid and protein contents of sweetpotatoes (Constantin et al., 1984). Nitrogen and potassium fertilizers are important for sweet potato in most depleted soils in the tropics, but whether application rates could affect the biochemical properties and cooking quality traits is unknown. Human health throughout the food value chain is of great concern as consumers have become health conscious. This study therefore, seeks to evaluate the effect of mineral fertilizer rates on biochemical properties, cooking quality traits and root yield of the improved sweetpotato varieties.

\section{Materials and Methods}

\section{Experimental Site}

The study was conducted in May, 2016 at CSIR-Crops Research Institute experimental field at Fumesua $\left(6^{\circ} 45^{\prime} 00.58^{\prime \prime} \mathrm{N} ; 1^{\circ} 31^{\prime} 51.28^{\prime \prime}\right.$ $\mathrm{W})$ in the semi-deciduous forest zone and Ejura $\left(7^{\circ} 24^{\prime} 46.73^{\prime \prime} \mathrm{N} ; 1^{\circ} 24^{\prime} 00.76^{\prime \prime} \mathrm{W}\right)$ in the forestsavannah transition zone during the major raining season. The rainfall pattern in the two study areas is bimodal with major (April-July) and minor (September-November). Detailed soil physico-chemical properties, agroclimatic conditions and cropping history of the study area can be found in Darko et al. (2020).

\section{Experimental Design}

The experiment design was $4 \times 4$ factorial in randomized complete block, with three replications. The four varieties of sweet potato used were Ligri, Bohye, Dadanyuie and Apomuden and four fertilizer amendments were T1: 30-30-30 kg /ha NPK; T2: 3030-60 kg NPK+50 kg Muriate of Potash; T3: 30-30-90 kg/ha NPK+ $100 \mathrm{~kg}$ Muriate of Potash and T4: Control (No fertilizer applied), where $\mathrm{T} 1$ to $\mathrm{T} 4$ represent treatments. 


\section{Land preparation}

Field preparation included slashing, ploughing and harrowing with a tractor and the plots were prepared into ridges using hoes and garden lines. Each plot measured $4 \times 4 \mathrm{~m}$ with $1 \mathrm{~m}$ space between rows and $0.3 \mathrm{~m}$ within rows. The length of a ridge was $4 \mathrm{~m}$ long, giving 12 plants per ridge.

\section{Planting materials}

Planting materials were obtained from Root and Tuber Division of CSIR-Crops Research Institute, Fumesua. Multiplication of the vine was done eight weeks prior to planting. Vine cutting used was $30 \mathrm{~cm}$ long having four or five nodes and planting was done manually.

\section{Fertilizer application}

The fertilizers used were NPK 15-15-15 and Muriate of Potash $\left(60 \% \mathrm{~K}_{2} \mathrm{O}\right)$. Fertilizer application of $200 \mathrm{~kg}$ NPK/ha 15-15-15 (30$30-30 \mathrm{~kg} / \mathrm{ha}$ NPK) was manually applied four weeks after planting on all the plots except the control. The second application was done eight weeks after planting as top dressing, using the sole potassium fertilizer (Muriate of Potash, $60 \% \mathrm{~K}_{2} \mathrm{O}$ ) where $30 \mathrm{~kg}$ and $60 \mathrm{~kg}$ of sole muriate of potash was added to treatments 2 and 3 increasing the number of potassium contents.

\section{Soil Sampling and Analysis}

Initial soil samples for analysis of physical and chemical properties were collected at $0-15 \mathrm{~cm}$ and $15-30 \mathrm{~cm}$ depth with the aid of a soil auger. The soil $\mathrm{pH}$ was measured using glass electrocalomel with a $\mathrm{pH}-$ meter on a $1: 2.5 \mathrm{soil} /$ water suspension (Daniels, 2016). Soil organic carbon was determined using the WalkleyBlack method (Daniels, 2016). Total nitrogen was determined by the Kjeldahl digestion and distillation procedure (Daniels, 2016). Bray and Kurtz's method no.1 extract and Nelson and
Sommers were used to determine the available phosphorus (Daniels, 2016). Potassium and sodium were determined by flame photometer procedure, whereas calcium and magnesium were determined by using ethylene diamine tetra acetic acid titration (Miller \& Arai, 2017).

\section{Root yield}

The root yield was determined by harvesting all the plants within the middle rows that were tagged. The harvested plants were counted, weighed and extrapolated per hectare using the equation below:

$$
\text { Root yield }(\mathrm{kg} / \mathrm{ha})=\frac{\text { Root yield }}{\text { Area }} \times 10,000 \mathrm{~m}^{2}
$$

Biomass yield

The above-ground biomass was computed using Equation 2

Biomass yield $=\frac{\text { Weight of biomass }(\mathrm{kg})}{\text { Area }} \times 10,000[2]$

Biochemical traits and sensory parameters

The biochemical traits determined were starch, beta-carotene, dry matter, zinc, iron, protein and sugar contents. Texture, taste and consistency were determined during the sensory evaluation.

Samples preparation and Biochemical analysis Samples were selected from the tagged plants per plot to determine the biochemical and cooking quality traits. The samples were washed with clean water to remove debris of soil and root hairs and stored on shelves for 24 hours to drain excess water. They were peeled and cut into four equal parts longitudinally. The two opposite quarters of the peeled storage roots were sliced into pieces of $50 \mathrm{~g}$ fresh sample weighted into a polyethylene envelope for each treatment. The samples were frozen at $-28^{\circ} \mathrm{C}$ for 24 hours and later sent to the vacuum freeze dryer kept at low pressure ( +1.9 - 5 torr) 
and low temperature $\left(-35-53^{\circ} \mathrm{C}\right)$ and freezedried for 72 hours. The freeze-dried samples were milled using the Wiley Mini Mill.

Near-Infrared Reflectance Spectrophotometer (NIRS) machine was used for the nutritional analysis. An XDS rapid content analyzer instrument made in Sweden with serial number 3013-0902 was used to scan the milled samples in the cuvettes. Approximately, $2 \mathrm{~g}$ of the milled samples of each treatment were placed in the Iris adaptor. The Infrared light passes through the samples to give all the biochemical or nutrient levels in the samples. These were used for the determination of biochemical traits (Tumwegamire et al., 2011) at the Quality and Nutrition Laboratory of the International Potato Centre (CIP) at CSIR-Crops Research Institute, Fumesua.

\section{Cooking quality assessment}

(Sensory evaluation)

Boiled storage roots were assessed by 20 farmers and field staff to evaluate the cooking quality traits such as texture, taste, and consistency. This is to ascertain the effects of fertilizer on boiled storage root of the improved sweetpotato varieties. Ten harvested diseasefree storage roots of similar sizes were selected for the sensory evaluation. The scale range used for the traits assessment ranged from 1- 3 as shown in Table 1.

TABLE 1

\begin{tabular}{|c|c|c|c|}
\hline & Scale 1 & Scale 2 & Scale 3 \\
\hline Texture & Dry & $\begin{array}{l}\text { Just about } \\
\text { right }\end{array}$ & Moist \\
\hline Taste & Sweet & $\begin{array}{l}\text { Just about } \\
\text { right }\end{array}$ & Not sweet \\
\hline Consistency & Hard & $\begin{array}{l}\text { Just about } \\
\text { right }\end{array}$ & Soft \\
\hline
\end{tabular}

Statistical Analysis

Two-way analysis of variance (ANOVA) was performed to test the differences among varieties and fertilizer rates using Genstat statistical package version 12. Treatment means were separated using least significance differences (LSD) at $\mathrm{P}<0.05$ probability level.

\section{Results and Discussion}

\section{Yield and yield components}

There were significant interactions $(\mathrm{P}<0.05)$ between variety and location in root and biomass yield (Table 2). Treatment factors, with exception of fertilizer, had significant influence on yield and yield components. Apomuden had the highest root yield (14.5 t// ha) while Dadanyuie had the lowest $(5.1 \mathrm{t} / \mathrm{ha})$ root yield across locations. Yield is dependent on the inherent genetic potential of the variety and the environmental conditions (Bryan et al., 2013). Better climatic conditions and genetic characteristics of the varieties contributed to the yield performance. Therefore, the differences in yield observed at different locations could be attributed to differences in agro-climatic conditions such as rainfall variation, temperature and relative humidity.

TABLE 2

Effect of varieties by locations interactions on yield and yield component of sweet potatoes

\begin{tabular}{llll}
\hline Varieties & Locations & $\begin{array}{l}\text { Root } \\
\text { yield } \\
(\mathbf{t} / \text { ha })\end{array}$ & $\begin{array}{l}\text { Biomass } \\
(\boldsymbol{t} / \boldsymbol{h a})\end{array}$ \\
\hline Apomuden & Ejura & 16.2 & 32.6 \\
Apomuden & Fumesua & 12.9 & 20.0 \\
Bohye & Ejura & 8.3 & 21.6 \\
Bohye & Fumesua & 8.0 & 20.5 \\
Dadanyuie & Ejura & 5.8 & 18.4 \\
Dadanyuie & Fumesua & 4.4 & 12.0 \\
Ligri & Ejura & 13.5 & 25.4 \\
Ligri & Fumesua & 6.8 & 11.4 \\
\hline Lsd (5\%) & & $\mathbf{5 . 6}$ & $\mathbf{4 . 2}$ \\
CV (\%) & & $\mathbf{5 1 . 9}$ & $\mathbf{3 6 . 6}$ \\
\hline
\end{tabular}

Source: (Stone, 2012) 
Biochemical properties Dry matter, starch and sugar contents

The result shows that Ligri had higher dry matter $(34.63 \%)$ and starch content $(65.87 \%)$ contents compared with Apomuden, which recorded $25.44 \%$ and $49.20 \%$ at Ejura (Table 3). Varietal effect was observed with Dadanyuie which recorded the highest dry matter content of $33.16 \%$ and Apomuden with the lowest dry matter yield of $21.06 \%$ (Table 3 ) at Fumesua. Apomuden had the highest sugar content (27.49\%) while Ligri had the lowest sugar content of $16.15 \%$ in Ejura. Similar results were recorded at Fumesua, but the starch content for Ligri and Apomuden were the lowest (Table 3). The variation in the dry matter, starch and sugar content among the sweetpotato varieties can be attributed to the differences in the genetic composition and environmental influences. The average dry matter content in sweetpotatoes is about 30\% (Woolfe, 1992), but varies widely depending on variety, climate, soil and cultivation practices. The high dry matter content signifies more carbohydrates and, consequently, a higher energy content (Gichuhi et al., 2014). High dry matter content promotes better marketing appeal, improves the shelf life and makes a better competitor in the food and starch industry. Dry matter content is used as a selection index for trait such as starch content and cooking quality among root and tuber crops.

The significant differences between starch contents of the varieties at the two locations might be explained in terms of differences in cultivar and climatic variations. Metabolic activity is temperature-dependent for the formation of starch-based on the cultivar. Similar to the results of this study, Brobbey (2015), observed that the amount of glycosides (sugar) found in cellular and ligneous membranes of sweet potato vary largely with the cultivars. This could explain the differences in sugar content among the varieties studied.

The fertilizer applied did not have any significant effect on biochemical properties measured in this study. This could be as a result of genotypic and environmental variation. The fertilizer could also be on a low side to have effect on the sweetpotato. It could also be attributed to intermitted rainfall pattern during the growing period. However, the application of fertilizer has been reported to influence the nutrient content of sweetpotato, especially the mineral content (Gichuhi et al., 2014). Several authors have reported an increased concentration of minerals in the sweetpotato leaves and roots with the increased application of fertilizer (Agbede, 2010). 
TABLE 3

Effect of fertilizers on dry matter, sugar and starch at Fumesua and Ejura

\begin{tabular}{lllllll}
\hline Treatments & \multicolumn{2}{l}{ Dry matter (\%) } & Sugar (\%) & \multicolumn{3}{c}{ Starch (\%) } \\
\hline Varieties & Ejura & Fumesua & Ejura & Fumesua & Ejura & Fumesua \\
Ligri & & & & & & \\
Bohye & 34.63 & 31.82 & 16.15 & 13.26 & 65.87 & 70.09 \\
Dadanyuie & 31.04 & 30.48 & 16.30 & 14.97 & 61.98 & 66.50 \\
Apomuden & 31.87 & 33.16 & 17.09 & 14.22 & 62.52 & 69.62 \\
LSD (5\%) & 25.44 & 21.06 & 27.49 & 28.60 & 49.20 & 50.61 \\
Fertilizer & $\mathbf{1 . 0 8}$ & $\mathbf{1 . 5 8}$ & $\mathbf{1 . 4 5}$ & $\mathbf{2 . 2 7}$ & $\mathbf{1 . 5 5}$ & $\mathbf{2 . 5 2}$ \\
$30-30-30$ & & & & & \\
$30-30-60$ & 31.82 & 29.34 & 18.56 & 17.69 & 61.20 & 64.89 \\
$30-30-90$ & 30.66 & 29.11 & 19.82 & 17.49 & 59.09 & 64.65 \\
$0-0-0$ & 30.47 & 28.74 & 19.32 & 17.96 & 59.77 & 63.91 \\
Lsd (5\%) & 30.05 & 29.33 & 19.32 & 17.91 & 59.09 & 63.38 \\
CV & NS & NS & NS & NS & NS & NS \\
\hline
\end{tabular}

Beta-carotene, Protein, Iron and Zinc Content The nutritional composition of tuber in terms of beta-carotene, protein, iron and zinc contents at harvest was not affected by fertilizer application. Beta-carotene in Apomuden was highest amongst the varieties and Dadanyuie recorded the least. Except for Apomuden, all the varieties recorded statistically similar values in most of the nutritional composition. Dadanyuie had the highest protein content of $6.65 \mathrm{mg} / 100$ $\mathrm{g}$ in Ejura while all the others were statistically similar. At Fumesua, Ligri recorded the highest protein content; the rest were statistically the same. Apomuden variety also recorded the highest iron and zinc content at both locations. The significant differences in beta-carotene content of sweetpotato evaluated could be due to differences in cultivars and climatic factors. According to literature (Grace et al., 2014; Wu et al., 2008), the amount of vitamin A found in sweet potato is quite wide and that the range of values within a specific vitamin depends primarily on the genetic composition of the cultivar, but there is strong interaction with management and environmental factors.

Apomuden had higher beta-carotene than the other varieties. Thus, there is a scope for Apomuden for increasing the vitamin A intake in Ghana. The results agree with findings by (Rose \& Vasanthakaalam, 2011), who reported that traditionally the white flesh varieties of sweetpotato are low in vitamin A (beta-carotene), as compared with the orange flesh varieties. Sweetpotato with appreciable amount of beta-carotene has the ability to increase blood levels and also helps to neutralize free radicals and reduce harmful substances that can increase the risk of several 
types of cancers (Islam et al., 2003; Woolfe, 1992).

In this study, fertilizer application did not have any observable effects on betacarotene. This contradicts the findings of other authors (Ali, 2019) who observed that $\mathrm{N}$ and $\mathrm{P}$ increased the carotene content of tuber roots during bulking and affect the unit weight of tuberous roots.

Protein content of many households in Ghana is derived mostly from foods of plant origin. The typical total protein content of sweet potato is as low as $1.5 \%$ fresh weight and as high as 5\% dry weight. However, it is superior to other roots and tubers, such as cassava, but may be inferior to cereals (Woolfe, 1992). The high protein content observed under some of the varieties in this study is significant since the inclusion of such varieties in the diet would help curb malnutrition.

In general, the white varieties, (Ligri and Dadanyuie) recorded the highest amount of dry matter and starch contents but contained very low amounts of sugar and betacarotene. The orange-flesh varieties Bohye and Apomuden in particular recorded the highest amount of beta-carotene and sugar contents but have low dry matter and starch content. The results are in line with findings by researchers (Aina et al., 2009; Baafi et al., 2016), who noticed positive association between sugar and beta-carotene and high dry matter and starch contents.

TABLE 4

Effect of fertilizer on biochemical properties at Fumesua and Ejura

\begin{tabular}{|c|c|c|c|c|c|c|c|c|}
\hline \multirow{2}{*}{ Treatments } & \multicolumn{2}{|c|}{ Beta-carotene(mg/100g) } & \multicolumn{2}{|c|}{ Protein (mg/100g) } & \multicolumn{2}{|c|}{ Iron $(\mathrm{mg} / 100 \mathrm{~g})$} & \multicolumn{2}{|c|}{ Zinc (mg/100g) } \\
\hline & Ejura & Fumesua & Ejura & Fumesua & Ejura & Fumesua & Ejura & Fumesua \\
\hline \multicolumn{9}{|l|}{$\underline{\text { Varieties }}$} \\
\hline Ligri & 0.00 & 0.00 & 5.64 & 5.77 & 2.14 & 2.02 & 1.17 & 1.16 \\
\hline Bohye & 0.92 & 2.32 & 5.36 & 4.55 & 2.38 & 2.03 & 1.26 & 1.06 \\
\hline Dadanyuie & 0.00 & 0.00 & 6.65 & 4.70 & 2.57 & 1.94 & 1.48 & 1.05 \\
\hline Apomuden & 30.72 & 34.05 & 5.14 & 4.63 & 2.65 & 2.53 & 1.58 & 1.51 \\
\hline LSD (5\%) & 0.91 & 1.52 & 0.91 & 0.61 & 0.19 & 0.16 & 0.4 & 0.10 \\
\hline \multicolumn{9}{|l|}{$\underline{\text { Fertilizer }}$} \\
\hline $30-30-30$ & 7.46 & 8.97 & 5.48 & 4.82 & 2.35 & 2.09 & 1.32 & 1.18 \\
\hline $30-30-60$ & 7.59 & 8.98 & 5.78 & 5.07 & 2.50 & 2.14 & 1.41 & 1.22 \\
\hline $30-30-90$ & 8.10 & 9.15 & 5.57 & 4.96 & 2.41 & 2.16 & 1.35 & 1.22 \\
\hline $0-0-0$ & 8.49 & 9.26 & 5.96 & 4.80 & 2.48 & 2.12 & 1.43 & 1.16 \\
\hline Lsd (5\%) & NS & NS & NS & NS & NS & NS & NS & NS \\
\hline $\mathrm{CV}$ & 13.9 & 20.1 & 19.3 & 15.1 & 9.6 & 9.0 & 12.2 & 10.2 \\
\hline
\end{tabular}




\section{Sensory evaluation}

The results obtained from the assessment of cooking quality traits of boiled storage root are presented in Figure 1-3. The taste tests by participants mainly farmers reveal that fertilizer application to sweetpotato do not have any negative effect on tuber cooking quality but, rather, it depends on individual varietal characteristic. Dadanyuie had good dry texture and excellent taste followed by Ligri while Apomuden had the lowest (Figure 1 $\& 2$ ). The trend of the results indicates that the white varieties had dry texture and sweet taste compared with the orange fleshed varieties. With the exception of Apomuden, which had the lowest rating for consistency, other varieties obtained high score for consistency (Figure $3)$. A variety with high dry matter content has excellent taste, texture or consistency than varieties with low dry matter.

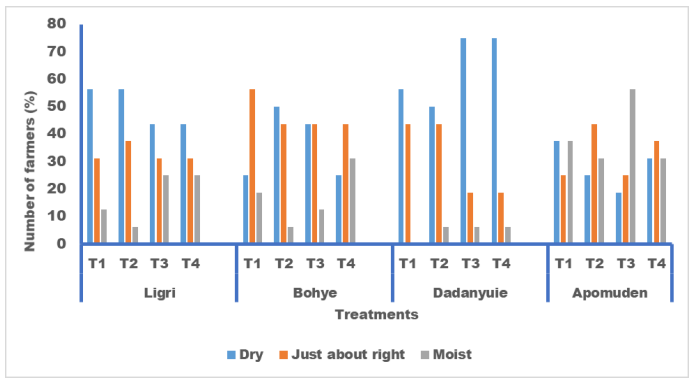

Fig. 1: Effect of fertilizer on texture of boiled sweetpotatoes

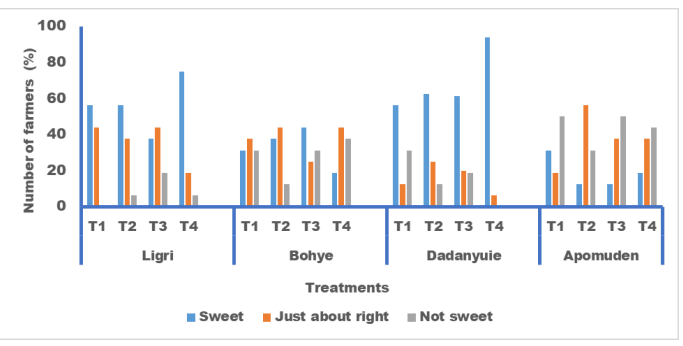

Fig. 2: Effect of fertilizer on taste of boiled sweetpotatoes

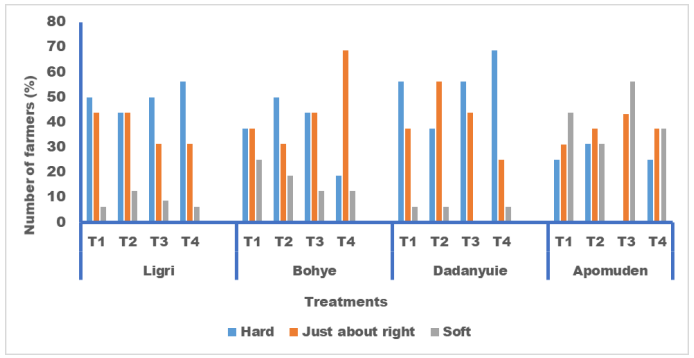

Fig. 3: Effect of fertilizer on consistency of boiled sweetpotatoes

\section{Conclusion}

The results obtained in this study showed significant varietal influence on root yield of sweetpotatoes across locations. Application of fertilizerdid not influence chemical composition (ß-carotene, starch, protein, zinc) and cooking quality (taste, texture, and consistency) traits of the sweetpotatoes. Also, it was found that the individual varietal characteristic determined their cooking quality traits. The highest content of $\beta$-carotene and protein was obtained under Apomuden and Bohye respectively. Ligri obtained high dry matter and starch content. The variation in $\beta$-carotene and other chemical compositions of the sweetpotato varieties can be useful in influencing sweetpotato research, production, and consumption with the view to curbing malnutrition challenges.

\section{REFERENCES}

Agbede, T.M. (2010) Tillage and fertilizer effects on some soil properties, leaf nutrient concentrations, growth and sweet potato yield on an Alfisol in southwestern Nigeria. Soil Tillage Research 110, 25 - 32. https://doi.org/10.1016/j. still.2010.06.003

Aina, A.J., Falade, K.O., Akingbala, J.O. \& Titus, P. (2009) Physicochemical properties of twenty-one Caribbean sweet potato cultivars. International Journal of Food Science and Technology 44, 1696 - 1704. https://doi.org/10.1111/j.13652621.2009.01941.x 
Ali, R.A. (2019) Effect of Nitrogen Fertilizer Types and Microelements on Growth, Yield and Chemical Constituents of Tuberous Root of Sweet Potato (Ipomoean batatas L, Lam). Alexandria Journal of Agriculture Science 64, 319 - 329.

https://doi.org/10.21608/alexja.2019.80488

Baafi, E., Manu-Aduening, J., Gracen, V.E., Ofori, K., Carey, E.E. \& Blay, E.T. (2016) Development of End-User Preferred Sweetpotato Varieties. Journal of Agriculture Science 8, p. 57. https://doi.org/10.5539/jas.v8n2p57

Brobbey, A. (2015) Growth, yield and quality factors of sweetpotato (Ipomoea batatas (L) Lam) as affected by seedbed type and fertilizer application. Thesis submitted to Kwame Nkrumah University OF Science and Technology, Kumasi (KNUST). School of Graduate Studies, Department of Crop and Soil Sciences.

Bryan, E., Ringler, C., Okoba, B., Roncoli, C., Silvestri, S. \& Herrero, M. (2013) Adapting agriculture to climate change in Kenya: Household strategies and determinants. Journal of Environment Management 114, 26 - 35.

https://doi.org/10.1016/j.jenvman.2012.10.036

Darko, C., Yeboah, S., Amoah, A., Opoku, A. \& Berchie, N. J. (2020) Productivity of sweet potato (Ipomoea batatas (L) Lam) as influenced by fertilizer application in different agro- ecologies in Ghana. Publisher: Scientific Africa

CRI. (2000) Crops Research Institute of Council for Scientific and Industrial Res. Ghana. Sweet Potato: The crop of the future. Factsheet.

Constantin, R., Jones, L., Hammett, H., Hernandez, T. \& Kahlich, C. (1984) The response of three sweet potato cultivars to varying levels of nitrogen. Journal of American Society of HorticultureScience 109, 610-614.

Daniels, W.L. (2016) The Nature and Properties of Soils, 15th Edition Ray R. Weil and Nyle C. Brady. Pearson Press, Upper Saddle River NJ, 2017. 1086 p. \$164.80. ISBN-10: 0-13-3254488; ISBN-13: 978-0-13-325448-8. Also available as eText for $\$ 67.99$. Soil Science Society of
American Journal 80, 1428 - 1428. https://doi. org/10.2136/sssaj2016.0005br

Dumbuya, G., Sarkodie-Addo, J., Daramy, M.A. \& Jalloh, M. (2016) Growth and yield response of sweet potato to different tillage methods and phosphorus fertilizer rates in Ghana. Journal of Experimental Biology and Agriculture Science 4, 475 - 483. https://doi. org/10.18006/2016.4(5).475.483

Ennin, S.S., Dapaah, H.K. \& Asafu-Agyei, J.N. (2007) Land preparation for increased sweetpotato production in Ghana, in: Proceedings of the $13^{\text {th }}$ ISTRC Symposium, 2007. $227-232$.

Ewell, P.T. \& Mutuura, J. (1994) Sweet potatoin the food systems of eastern and southern Africa. Acta Horticulture, 405 - 412. https://doi. org/10.17660/actahortic.1994.380.63

Gichuhi, P.N., Kpomblekou-A, K. \& Bovell-Benjamin, A.C. (2014) Nutritional and physical properties of organic Beauregard sweet potato [ Ipomoea batatas (L.)] as influenced by broiler litter application rate. Food Science and Nutrition 2, 332 - 340. https://doi.org/10.1002/fsn3.108

FAO. (2009) Food Security and Agricultural Mitigation in Developing Countries: Options for Capturing Synergies. Rome, Italy. www.fao.org/ docrep/012/i1318e/i1318e00.pdf.

Global food security index (GFSI) (2012) An assessment of food affordability, availability and quality. A report from the Economist Intelligence Unit.

Grace, M.H., Yousef, G.G., Gustafson, S.J., Truong, V. Den, Yencho, G.C. \& Lila, M.A. (2014) Phytochemical changes in phenolics, anthocyanins, ascorbic acid, and carotenoids associated with sweetpotato storage and impacts on bioactive properties. Food Chemistry 145, 717 - 724. https://doi.org/10.1016/j.foodchem.2013.08.107

Hoppenstedt, Z.N., Griffin, J.J., Pliakoni, E.D. \& Rivard, C.L. (2017) Yield, Quality, and Performance of Organic Sweetpotato Slips Grown in High Tunnel Compared with Open Field, 1 - 11. https://doi.org/10.21273/HORTTECH04139-18 
Islam, M.S., Yoshimoto, M. \& Yamakawa, O. (2003) Distribution and physiological functions of caffeoylquinic acid derivatives in leaves of sweetpotato genotypes. Journal of Food Science 68, 111 - 116. https://doi. org/10.1111/j.1365-2621.2003.tb14124.x

Kareem, I. (2013) Growth, Yield and Phosphorus Uptake of Sweet Potato ( Ipomoea batatas ) Under the Influence Phosphorus Fertilizers. Research Journal of Chemistry Environment and Science $1,50-55$.

Miller, A.P. \& Arai, Y. (2017) Effects of extraction time and phosphorus speciation on soil test phosphorus data: A case study of Illinois agricultural soils. Geoderma 305, 62 - 69. https:// doi.org/10.1016/j.geoderma.2017.05.043

Neela, S. \& Fanta, S.W. (2019) Review on nutritional composition of orange-fleshed sweet potato and its role in management of vitamin A deficiency. Food Science and Nutrition. https://doi. org/10.1002/fsn3.1063

Obeng-Bio, E. (2018) Genetic analysis of grain yield and other traits of early maturing provitamin A - Quality protein maize inbreed lines under drought and low soil nitrogen conditions. University of Ghana.

Onuh, J., Akpapunam, M. \& Iwe, M. (2005) Comparative Studies Of The Physicochemical Properties Of Two Local Varieties Of Sweet Potato Flours. Nigerian Food Journal 22. https://doi. org/10.4314/nifoj.v22i1.33579
Rose, I. \& Vasanthakaalam, H. (2011) Comparison of the Nutrient composition of four sweet potato varieties cultivated in Rwanda. American Journal of Food and Nutrition 1, 34 - 38. https://doi. org/10.5251/ajfn.2011.1.1.34.38

Stone, H. (2012) Sensory Evaluation Practices, Sensory Evaluation Practices. https://doi.org/10.1016/ C2009-0-63404-8

Tumwegamire, S., Rubaihayo, P.R., LaBonte, D.R., Diaz, F., Kapinga, R., Mwanga, R.O.M. \& Grüneberg, W.J. (2011) Genetic diversity in white- and orange-fleshed sweetpotato farmer varieties from East Africa evaluated by simple sequence repeat markers. Crop Science 51, 1132 - 1142. https://doi.org/10.2135/cropsci2010.07.0407

Waha, K., van Wijk, M.T., Fritz, S., See, L., Thornton, P.K., Wichern, J. \& Herrero, M. (2018) Agricultural diversification as an important strategy for achieving food security in Africa. Global Change Biology 24, 3390 - 3400. https:// doi.org/10.1111/gcb.14158

Woolfe, J.A. (1992) An untapped food resource. Cambridge University Press, UK.

Wu, D. mei, Lu, J., Zheng, Y. lin, Zhou, Z., Shan, Q., Ma, D. (2008) Purple sweet potato color repairs d-galactose-induced spatial learning and memory impairment by regulating the expression of synaptic proteins. Neurobiology Learning and Memory 90, 19 - 27. https://doi.org/10.1016/j. nlm.2008.01.010 